\title{
Sahiplik Yoğunlaşmasının Temettü Dağıtım Kararlarına Etkisi: Borsa İstanbul'da Bir Uygulama
}

\author{
The Impact of Ownership Concentration on Dividend Payout Policy: Evidence From Turkey
}

\author{
Ersan ERSOY ${ }^{1}$, Emin Hüseyin ÇETENAK ${ }^{2}$
}

\section{ÖZET}

$\mathrm{Bu}$ çalışmada sahiplik yoğunlaşmasının temettü dağıtım kararları üzerine etkisi araştırılmıştır. Rassal Etkili Tobit ve Sistem Genelleştirilmiş Momentler Metodunun kullanıldığı çalışmada, Borsa İstanbul'a kote 116 sanayi şirketinin 2004 2009 dönemi verilerinden faydalanılmıştır. Elde edilen bulgular, sahiplik yoğunlaşmasının temettü verimini pozitif yönde etkilediğini göstermektedir. Ayrıca firmaların karlılık oranı, borçlanma düzeyi, yatııım harcamaları ve Piyasa Değeri/Defter Değeri oranının temettü dağıtım kararları üzerinde önemli bir etkiye sahip olduğu tespit edilmiştir. Sadece kar dağıtan firmalar göz önünde bulundurulduğunda, yoğunlaşma düzeyini temsil eden tüm kukla değişkenler ile karlılık, piyasa değeri ve yatııım değişkenlerinin firmaların kar dağıtım oranlarını belirlediği görülmektedir. Kar dağıtan firmalardan oluşan örneklem, düşük ve yüksek hızda büyüyen firmalar şeklinde iki gruba ayrıldığında, düşük hızda büyüyen firmaların temettü dağıtım kararlarında sahiplik yoğunlaşmasının herhangi bir etkisinin olmadığı görülmüştür. Hızlı büyüyen firmalarda ise temettü dağıtım kararlarının sahiplik yoğunlaşması, karlılık, piyasa değeri ve yatırım harcamaları tarafından belirlendiği ortaya konulmuştur.

Anahtar Kelimeler: Temettü Politikası, Sahiplik Yoğunlaşması, Sahiplik Yapısı

\section{GíRiş}

Modigliani ve Miller (1961)'in temettü politikasının firmaların piyasa değeri üzerinde etkisinin olmadığını ileri süren temel çalışması ile birlikte özellikle temettü politikasının piyasa değerine etkisi ile ilgili literatürde yoğun bir tartışma başlamıştır. Bazı firmalar daha fazla temettü dağıtırken neden bazı firmaların daha az temettü dağıttığı, temettü dağıtımını hangi faktörlerin etkilediği, temettü dağıtımının yatııımı tercihlerini ve firma değerini etkileyip etkilemediği konularında çeşitli teorik yaklaşımlar geliştirilmiş ve konu ile ilgili çok sayıda çalışma yapılmıştır. Temettü politikası kararlarının açıklanmaya çalışılması ile ilgili olarak Black (1976), bunun çok zor olduğunu ifade etmiş ve temettü bilmecesi (dividend puzzle) ifadesini kullanmıştır. Karlılık, yatııım planları, borçlanma düzeyi ve yasalar gibi temettü politikasını etkileyen çeşitli

\begin{abstract}
In this study, we investigated the effect of ownership concentration on dividend payout decision. To this end, by using Random Effect Tobit Model and System Generalized Method of Moments approach we utilized the data of 116 industrial companies that are listed on the Borsa Istanbul for the period 2004-2009. The results suggest that there is a positive relationship between ownership concentration and dividend yield. In addition to concentration, firms' profitability, leverage degree, capital expenditures and market to book value ratio also have significant impact on the dividend decision. Only considering profit distributing firms, concentration level dummy variables, profitability, market value and investment variables seems to determine the dividend rate for the company. When we divide this sample into two subgroups according to asset growth rates of the firms, dividend decisions of slow growing firms are affected by return on asset, market to book ratio as well as ownership concentration. On the other hand, ownership concentration, profitability, capital expenditures and market value are important factors for the dividend payout decisions of fast growing companies.
\end{abstract}

Keywords: Dividend Policy, Ownership Concentration, Ownership Structure

faktörler vardır. Bu faktörlerden biri de sahiplik yapısıdır. Bu çalışmada sahiplik yapısı değişkenlerinden biri olan sahiplik yoğunlaşmasının temettü dağıtım kararları üzerine etkisi araştırıımıştır.

Firmaların özkaynak yapıları sahiplik bakımından incelendiğinde birbirinden farklı sahiplik yapılarının olduğu görülmektedir. Örneğin özkaynakların büyük kısmı bazı firmalarda belirli bir aileye ait iken, bazı firmalarda bir holdinge veya bir kurumsal yatırımcıya aittir. Bazı firmalarda özkaynakların büyük bir kısmı devlete ait iken, bazı firmalarda yabancı bir kişi veya şirkete ait olmakta, bazı firmalarda ise halka açıklık oranının yüksek olması nedeniyle özkaynakların büyük kısmı geniş bir yatııımcı tabanına yayılmaktadır. Sahiplik yapısında farklılık yaratan unsurlardan biri de sahiplik yoğunlaşmasıdır. Sahiplik yoğunlaşması (ownership concentration, blockholder ownership), bir firmanın özkaynaklarının büyük bir kısmına bir veya 
birkaç kişinin sahip olması, dolayısıyla firma üzerindeki mülkiyet hakkının ve kontrol gücünün bir veya birkaç kişide toplanmasıdır.

Sahiplik yoğunlaşması ile ilgili tartışmalar Berle ve Means (1932)'in "The Modern Corporation and Private Property" adlı çalışmasına kadar dayanmaktadır. Berle ve Means (1932), sahiplik yoğunlaşması ile firma performansı arasında pozitif bir ilişki olduğunu, sahiplik yoğunlaşmasındaki azalmanın firma performansını olumsuz yönde etkileyeceğini ileri sürmüştür. Demsetz (1983) ve Demsetz ve Lehn (1985) ise yaptıkları çalışmada, sahiplik yoğunlaşmasındaki değişikliklerin karlılık oranı üzerinde bir etkisinin olmadığını tespit etmiştir. Shleifer ve Vishny (1986; 1997), sahiplik yoğunlaşmasının varlığının, yönetimin performansının değerlendirmesi ve denetlemesinde teşvik edici bir unsur olduğunu belirtmiş ve dolayısıyla sahiplik yoğunlaşmasının var olması durumunda yöneticilerin daha iyi gözetim altında tutulacağını ileri sürmüştür. Shleifer ve Vishny (1997), ayrıca büyük hissedarların bazı durumlarda (örneğin oy hakkının \% 51 veya daha fazlasının ellerinde bulunması durumunda) yönetime baskı yapabilecek ve hatta yönetimi değiştirebilecek düzeyde yeterli oy hakkına sahip olduklarını belirtmiştir. Büyük hissedarların, yönetimin daha sıkı denetlenmesi ve gözetlenmesi konusunda daha yüksek bir güç ve güdüye sahip olmaları nedeniyle, sahiplik yoğunlaşmasının olduğu firmalarda sahiplik ve yönetim ayrımından kaynaklanan temsil problemlerinin ${ }^{1}$ daha az olacağını ileri sürmüştür. Fakat sahiplik yoğunlaşmasının bahsedilen faydalarının yanında bazı maliyetlerinin de olduğunu ifade eden Shleifer ve Vishny (1997)'ye göre, en temel problemlerden biri, büyük hissedarların çıkarlarının, firmadaki diğer hissedarların çıkarları veya çalışanlar ve yöneticilerin çıkarları ile çatışması halinde, büyük hissedarların kontrol güçlerini kendi refahlarını maksimize etmek için kullanmalarıdır. Dolayısıyla sahiplik yoğunlaşması bir yandan sahiplik ve yönetim ayrımından kaynaklanan temsil problemlerinin azalmasına yardımcı olurken, diğer yandan büyük ve küçük hissedarlar arasında temsil problemlerinin ortaya çıkmasına neden olabilmektedir. Büyük hissedarların varlığı temsil probleminin çözümünde oldukça etkili olabilmesine rağmen, servetin etkin olmayan bir şekilde diğer yatırımcılardan kendilerine doğru yeniden dağıtımının yapılmasına da neden olabilmektedirler.

Finans literatüründe tartışılan konulardan biri de, firmaların sahiplik yapılarındaki farklılıkların, finansman kararları ve temettü politikası gibi temel finansal karar alanları üzerinde nasıl bir etkisinin olduğudur. Sahiplik yapılarındaki farklılıkların, firma sahip ve/veya yöneticileri tarafından alınacak finansal kararları etkile- mesi kaçınılmazdır. Örneğin sahiplik yoğunlaşmasının söz konusu olduğu firmalarda yönetim doğal olarak sahipliği elinde bulunduran büyük ortaklar tarafından şekillenecek ve kararlar büyük ortakların istek ve beklentilerine uygun şekilde verilebilecektir. Sahiplik yoğunlaşmasının olduğu firmalar ile sahipliğin dağınık olduğu diğer bir ifadeyle mülkiyetin daha fazla tabana yayıldığı firmaların temettü politikaları arasında da farklılık olabilecektir. Nitekim literatürde, temettü politikasının sahiplik yapısından etkilendiğini ortaya koyan birçok çalışma vardır (Rozeff, 1982; Easterbrook, 1984; Faccio vd., 2001; Gugler, 2003; Mancinelli ve Ozkan, 2006). Örneğin Mancinelli ve Ozkan (2006), büyük hissedarların kendi çıkarları için kullanacakları, kontrolleri altındaki serbest fonların miktarını artırma güdüsüne sahip olabileceklerini belirtmiştir. Dolayısıyla, sahiplik yoğunlaşmasının olduğu firmalarda, sahiplik yoğunlaşmasının olmadığı dağınık sahiplik yapısına sahip firmalara kıyasla daha az temettü ödemesi yapılmak suretiyle, daha fazla nakit tutabilecektir.

Büyük hissedarlar ile küçük hissedarların temettüye bakış açıları arasındaki farklılıklar ve temsil maliyetlerini azaltma isteği gibi nedenlerle firmaların sahiplik yoğunlaşmasındaki farklılıklar, farklı temettü politikalarının şekillenmesine neden olabilir. Holderness (2003), bu konunun literatürde yeterince incelenmediğini belirtmiştir. Abdullah vd. (2012)'a göre, literatürde temettü politikasını temsil maliyeti ve sahiplik yapısı temelinde açıklamaya çalışan sınırlı sayıda çalışma vardır. Ayrıca firmaların temettü ödeme politikasının, beklenen temsil maliyetlerini azaltmada etkili olduğu kadar, aynı zamanda sahiplik ve kontrol yapısına bağlı olabildiğine de dikkat etmek gerekmektedir.

Temsil teorisinde, temettü politikası kararlarının temsil problemlerini azaltmak amacıyla kullanılabileceği ileri sürülmektedir (Ramli, 2010: 171). Rozeff (1982), maliyet minimizasyonu yaklaşımı ile, firmaların temsil ve işlem maliyetleri toplamını minimum kılan optimum bir temettü dağıtım oranının olduğunu göstermiştir. Çalışmada temettü ödemelerinin temsil maliyetlerini azaltmada kullanılabileceği, temettü dağıtım oranı arttıkça temsil maliyetlerinde azalma olacağı ifade edilmiştir. Ayrıca çalışmada, firma dışından yatırımcıların (outside shareholders) özkaynakların önemli bir kısmına sahip olması ve sahipliklerinin dağınık olması halinde daha yüksek düzeyde temettü talep edecekleri hipotezi ile uyumlu sonuçlar elde edilmiştir. Temettü dağııım oranının, firma içinden yatırımcılar (insider shareholders) tarafından tutulan hisse senetlerinin yüzdesinin anlamlı bir şekilde negatif bir fonksiyonu olduğu ve firmanın adi hisse senedi sahiplerinin sayısı ile de anlamlı bir şekilde pozitif bir fonksiyonu olduğu tespit edilmiştir. 
Easterbrook (1984), firmaların yeni fon bulmak için sermaye piyasalarına başvurmaları durumunda, sermaye piyasalarının gözetimi altına girecekleri için yöneticilerin gözetim maliyetlerinin daha düşük bir düzeyde gerçekleşeceğini ileri sürmüştür. Temettü dağıtım oranının artırılması durumunda, yöneticiler intiyaç duyulan fonları karşılamak üzere sermaye piyasalarına daha sık başvurmak zorunda kalacaklar ve bu sayede sermaye piyasası tarafından daha sık ve etkin bir şekilde denetlenecekler, izleneceklerdir. Ayrıca bu durum, sermaye piyasalarının gözetimi altında oldukları için yöneticileri risk alma konusunda daha dikkatli davranmaya itecektir. Sermaye piyasalarının daha etkin bir şekilde gözetimi altında olmaları, yöneticilerin hissedarların çıkarlarına zarar verecek kararlar verme olasılıklarını ve dolayısıyla temsil maliyetlerinin azalmasını sağlayacaktır. Ayrıca yöneticiler, sermaye piyasalarında yeni çıkaracakları menkul kıymetlerin daha yüksek bir fiyattan işlem görme olasıllı̆ını artırmak için temsil maliyetlerini azaltma konusunda daha yüksek bir güdüye sahip olacaklardır.

Jensen (1986), önemli miktarda serbest nakit akımına sahip bir yöneticinin, elindeki fonları temettü ödemelerini artırmak için veya hisse senetlerinin geri satın alımında kullanmaması durumunda, bu fonların düşük getirili yatırım projelerine yatırım yapmada veya gereksiz harcamalarda kullanılabileceğini ileri sürmüştür. Dolayısıyla temettü dağıtım miktarının artırılması, yöneticilerin kullanabilecekleri serbest nakit akımlarını azaltacak ve yöneticilerin bu fonları kendi kişisel çıkarları için, lüks veya gereksiz harcamalarda kullanma olasılıklarını azaltıp kaynak kullanım etkinliğini artıracaktır. Sonuç olarak bu durum, yönetici ve hissedarlar arasındaki serbest nakit akımlarından kaynaklı temsil problemlerini azaltabilecektir.

La Porta vd. (2000)'nin çalışmasında, yatırımcılar arasındaki (corporate insiders and outsiders) temsil problemlerini çözmede temettülerin faydalı bir rol oynayabileceği belirtilmiş ve temsil maliyetlerinin temettü politikası üzerine etkisi araştırılmıştır. Çalışmada, hissedarların korunma kalitesi temsil maliyetinin bir göstergesi olarak ele alınmış ve iki hipotez ortaya atılmıştır. Birincisinde, temettü ödemeleri hissedarların yasal korunmalarının bir çıktısı olarak ifade edilmiştir. Bu hipoteze göre hissedarlarının haklarının iyi bir şekilde korunduğu yasal rejimlerde, daha yüksek temettü dağıtımı beklenmektedir. İkincisinde ise, temettü ödemelerinin hissedarların yasal korunmasının yerine geçeceği, onu ikame edeceği ifade edilmiştir. Bu hipoteze göre hissedarların yasal korunmalarındaki eksikliklerin daha yüksek temettü ödemeleri ile telafi edileceği beklenmektedir.
Gugler (2003) ise büyük hissedarların temettü dağıtım politikası üzerine etkisinin, firmaların sahip olduğu yatırım fırsatlarına bağlı olduğunu iddia etmiştir. Gugler (2003)'e göre iyi yatırım fırsatlarının olduğu bir firmanın hissedarları, büyüme fırsatlarını hayata geçirmek için temettü ödemelerini erteleyebilirler. Diğer taraftan, çok az veya hiç büyüme fırsatı olmayan bir firmanın hissedarları ise; elde edilen kar firma içinden yatırımcıların çıkarları için kullanılabilir düşüncesiyle, temettü dağıtımı yapılması amacıyla firma içinden yatırımcılara baskı yapmak isteyebileceklerdir.

Harada ve Nguyen (2006), sahiplik yoğunlaşmasının temettü dağıtım politikasına etkisi ile ilgili iki farklı yaklaşımdan bahsetmiştir. Easterbrook (1984) ve Jensen (1986)'in argümanına dayanan birinci yaklaşımda, temettü dağıtımının, yöneticilerin elindeki fazla serbest nakit akımını sınırlaması ve daha fazla finansal disiplin altına girmesini sağlaması yoluyla hissedar denetiminin yerine geçeceğini ileri sürmüştür. Bu yaklaşımın geçerli olduğu varsayıldığında, sahiplik yoğunlaşmasının daha yüksek bir temettü dağıtım oranı ile ilişki içinde olması beklenir. Shleifer ve Vishny (1997)'in argümanlarına dayanan alternatif yaklaşım ise büyük hissedarların, kontrolleri altındaki firma kaynaklarını kendi kişisel çıkarları için kullanabilecekleri düşüncesine dayanmaktadır. Dolayısıyla bu yaklaşımda, büyük hissedarların söz konusu tercihlerinden dolayı temettü dağıtım oranının daha düşük olacağı ileri sürülmektedir.

Bu çalışmanın amacı, sahiplik yoğunlaşmasının temettü dağıtım kararları üzerine etkisini araştırmaktır. Yatırımcılar hisse senetlerinden sermaye kazancı, rüçhan hakkı ve temettü kazancı sağlayabilirler. Sahiplik yoğunlaşması ile temettü dağıtım kararları arasındaki ilişkinin bilinmesi, özellikle temettü kazancına önem veren gerek bireysel gerekse kurumsal yatırımcıların yatırım kararlarında faydalı bilgiler sunacak ve yol gösterici olacaktır. Ayrıca Türkiye'de sahiplik yoğunlaşması ile temettü dağıtım kararları arasındaki ilişkiyi spesifik olarak inceleyen bir çalışmaya rastlanamamıştır. Bu nedenle çalışmanın literatürdeki bu boşluğu doldurmaya katkı sağlayacağı düşünülmektedir.

Çalışma beş bölümden oluşmaktadır. Giriş bölümünü takip eden ikinci bölümde literatür taramasına yer verilmiştir. Üçüncü bölümde çalışmada kullanılan veri yapısı ve yöntem anlatılmış, dördüncü bölümde çalışmadan elde edilen bulgular değerlendirilmiştir. Beşinci bölümde ise çalışmadan elde edilen sonuçlar yer almaktadır. 


\section{LITERATÜR}

Literatürde, sahiplik yoğunlaşmasının temettü politikasına etkisini araştıran çok sayıda çalışma vardır. Thomsen (2005), 1988-1998 döneminde Avrupa Birliği ve Amerika'da en büyük firmalarda sahiplik yoğunlaşması, temettü politikası ve firma değeri arasındaki ilişkiyi araştırmıştır. Amerika ve İngiltere ile karşılaştırıldığında, Kıta Avrupa'sındaki firmalarda sahiplik yoğunlaşması düzeyinin daha yüksek olduğu tespit edilmiştir. Çalışmadan elde edilen sonuçlar, Amerika, İngiltere ve Avrupa'da firmaların sahiplik yoğunlaşmasındaki artışın daha düşük temettü ödemesi ile ilişkili olduğunu göstermiştir.

Faccio vd. (2001), 1992-1996 döneminde birden fazla büyük hissedarın varlığının, Avrupa'da temettü ödeme oranını pozitif yönde, Asya'da ise negatif yönde etkilediğini tespit etmiştir. Gugler ve Yurtoglu (2003), 1992-1998 döneminde Almanya'da, firmaların temettü ödeme oranı ile en büyük hissedarın sahiplik oranı arasında negatif, ikinci en büyük hissedarın sahiplik oranı arasında ise pozitif bir ilişki olduğunu tespit etmiştir. Smit ve Eije (2009) ise Almanya'da 2005-2008 döneminde, sahiplik yoğunlaşmasının ne nakit temettü dağıtımı yapılıp yapılmama kararını ne de nakit temettü ödeme miktarını etkilemediğini tespit etmiştir. Maury ve Pajuste (2002), 1995-1999 döneminde Finlandiya'da firmaların sahiplik yoğunlaşması ile temettü ödeme oranı arasında negatif bir ilişki olduğu sonucuna ulaşmıştır. Elde edilen bu sonuç, daha az temettü dağıtılmasının, firmadaki hakim hissedarların küçük hissedarlar ile paylaşılmayacak şekilde kendilerine özel çıkarlar yaratma çabası içinde olmalarının bir işareti olarak kabul edilebileceği şeklinde yorumlanmıştır.

Chen vd. (2005), Hong Kong'da 1995-1998 döneminde aile sahipliği yoğunlaşması, firma performansı ve temettü politikası arasındaki ilişkiyi incelemiştir. Çalışmada toplam özkaynaklardaki aile sahipliğinin payı, diğer bir ifadeyle aile sahipliği yoğunlaşması 3 gruba ayrılmıştır (\%0-\%10, \%10-\%35, \%35-\%100). Örneklem, hem tüm dönem hem de küçük piyasa kapitalizasyonuna sahip firmalar ve yüksek piyasa kapitalizasyonuna sahip firmalar olmak üzere 2 alt gruba ayrılmıştır. Çalışmada, aile sahipliği yoğunlaşması ile temettü politikası arasında zayıf bir ilişki bulunmuştur. Sadece küçük piyasa değerine sahip firmalar örnekleminde, aile sahipliği yoğunlaşmasının \% 10 ile \% 35 arasında olduğu firmalar için temettü verimi ile aile sahipliği yoğunlaşması arasında pozitif, aile sahipliği yoğunlaşmasının \%0-\%10 arasındaki firmalar için ise negatif yönlü bir ilişki bulunmuştur. Temettü veriminin bağımlı değişken olduğu diğer örneklemlerde ve temettü dağıtım oranının bağımlı değişken olduğu modellerin tamamında, aile sahipliği yoğunlaşması ile temettü politikası arasında istatistiksel olarak anlamlı bir ilişki bulunamamıştır.

Harada ve Nguyen (2006), 1995-2002 döneminde Japon firmalarda sahiplik yoğunlaşması ile temettü politikası arasındaki ilişkiyi, Shleifer ve Vishny (1997)'nin firmadaki büyük hissedarların, kendi kontrolleri altındaki firma kaynaklarını özel çıkarları için kullanma istekleri nedeniyle daha az temettü dağıtacaklarını ileri süren hipotezi çerçevesinde incelemiştir. Çalışmada, söz konusu hipotezle de uyumlu olarak, temettü politikasının sahiplik yoğunlaşması ile negatif yönde ilişkili olduğu, sahiplik yoğunlaşmasının yüksek olduğu firmaların daha az temettü ödedikleri tespit edilmiştir. Khan (2006), 1985-1997 döneminde İngiliz firmaları için benzer bir sonuca ulaşmış ve temsil maliyeti yaklaşımı ile uyumlu şekilde sahiplik yoğunlaşmasının ödenen temettü tutarını azalttığını tespit etmiştir. Mancinelli ve Ozkan (2006) da çalışmasında, İtalya'da en büyük hissedarların oy haklarındaki artışın, firmaların temettü ödeme oranı üzerinde negatif bir etkiye sahip olduğu sonucuna ulaşmıştır.

Ahmed ve Javid (2009), 2001-2006 döneminde Pakistan Karachi Borsasında işlem gören firmaların temettü dağıtım politikalarını incelemiştir. Sadece temettü dağıtan firmalar ile temettü dağıtan ve dağıtmayan firmalardan oluşan iki farklı veri setinin kullanıldığı çalışmada, hisse senetlerinin \%5'inden daha fazlasını elinde bulunduran hissedarların sayısı ile temettü verimi arasında pozitif bir ilişki bulunmuştur. Ramli (2010), 2002-2006 döneminde Malezya'da sahiplik yoğunlaşmasının temettü politikası üzerine etkisini araştırmıştır. Büyük hissedarların var olduğu firmalarda, daha az temettü dağıtmak yoluyla servetin küçük hissedarlardan büyük hissedarlara aktarılabilmesi yaklaşımının tersine, en büyük hissedarın sahiplik oranı arttıkça temettü ödeme oranının da arttığı tespit edilmiştir. Ayrıca ikinci en büyük hissedarın varlığının da temettü ödeme oranı üzerinde pozitif ve anlamlı bir etkiye sahip olduğu görülmüştür. Abdullah vd. (2012) de benzer bir sonuca ulaşmıştır. 2010 yılında Malezya'da sahiplik yapısı değişkenlerinden sadece sahiplik yoğunlaşmasının temettü dağıtımını pozitif ve istatistiksel olarak anlamlı bir şekilde etkilediğini bulmuştur. Bu bulgunun Shleifer ve Vishny (1986)'nin bulgularını desteklediği ve sahiplik yoğunlaşmasının bir anlamda hissedar denetiminin yerine geçip, daha fazla serbest nakit akımının temettü olarak dağıtılması nedeniyle firma kaynaklarının düşük getirili yatırım projelerinde kullanılma olasılığını azaltmak suretiyle firma değerinin maksimize edilmesine yardımcı olacağı ifade edilmiştir. Ayrıca temsil teorisinden yola çıkarak, yüksek temettü ödemelerinin hissedar dene- 
timinin yerine geçerek, temsil maliyetlerini azaltmada kullanılabileceği sonucuna ulaşılmıştır.

Sharif vd. (2010), 2002-2008 döneminde İran'da yüksek düzeyde sahiplik yoğunlaşmasına sahip firmaların daha fazla temettü dağıttığını, ayrıca en büyük beş hissedarın sahiplik oranının temettü ödeme oranı üzerinde pozitif bir etkiye sahip olduğunu tespit etmiş̧ir. Rezaloie vd. (2013), 2007-2010 döneminde sahiplik yoğunlaşması ile temettü ödeme oranı arasında pozitif bir ilişki bulmuştur. Mehrani vd. (2011), İran'da 2000-2007 döneminde yoğunlaşmış kurumsal sahiplik ile temettü ödeme oranı arasında pozitif bir ilişki bulmuştur. Habibi vd. (2012) ise 2005-2011 döneminde İran'da firmaların sahiplik yoğunlaşması ile temettü politikası arasında herhangi bir ilişki bulamamıştır. Al-Shubiri vd. (2012), Ürdün'de sahiplik yapısı ile temettü politikası arasındaki ilişkiyi incelemiştir. 2005-2009 dönemini kapsayan çalışmada, sahiplik yapısının firmaların temettü politikası ile yakın ilişki içinde olduğu, en büyük beş ortağın sahiplik payının daha fazla olması durumunda temettü ödemelerinin de daha fazla olduğu görülmüştür. Thanatawee (2013), 2002-2010 döneminde Tayland'da firmaların daha yüksek sahiplik yoğunlaşmasına sahip olması veya en büyük hissedarın bireysel bir yatırımcı değil de bir kurum olması halinde daha fazla temettü dağıttıklarını tespit etmiş̧ir.

Gürsoy ve Aydoğan (1999)'ın 1992-1998 dönemini kapsayan çalışmasında, Türk firmalarında sahiplik yoğunlaşmasının hem firma performansı hem de firmaların risk almadaki tutumu üzerine anlamlı bir etkiye sahip olduğu, daha fazla sahiplik yoğunlaşmasının daha iyi bir piyasa performansına yol açtığı tespit edilmiştir.

Yıldız vd. (2014), 2003-2010 döneminde Borsa İstanbul'da işlem gören sanayi firmalarının temettü politikalarını etkileyen unsurları araştırmışlardır. Çalışmada, toplam hisse senedi adedinin en az \% 5 oranına denk gelen hisse senedi sayısını elinde bulunduran ortak sayısı ile ölçtükleri sahiplik yapısı değişkeninin, firmaların temettü politikaları üzerinde bir etkisinin bulunmadığı görülmüştür.

\section{VERI YAPISI VE YÖNTEM}

Bu çalışmada sahiplik yoğunlaşmasının temettü dağıtım kararlarına etkisini test etmek için Borsa İstanbul'a kote 116 sanayi şirketinin 2004-2009 yılları arasındaki verilerinden faydalanılmıştır. Veriler Borsa İstanbul'un ve Kamuyu Aydınlatma Platformu'nun internet sitesinden ve Datastream veri tabanından alınmıştır. Çalışmada, hem Rassal Etkili Tobit Modeli hem de dinamik panel tahmin yöntemlerinden biri olan ve son yıllarda iktisat ve finans literatüründe sıklıkla kul-
Ianılan Genelleştirilmiş Momentler Metodunun sistem versiyonu kullanılmıştır. Bilindiği üzere panel veri analizleri, hem yatay hem dikey kesitler içerdiğinden daha fazla veri kullanımına olanak sağlar. Bu sayede daha fazla bilgi ve serbestlik derecesi sunar. Bunun yanında zaman serisi ve yatay kesit verisi analizlerinden farklı olarak heterojenlikleri kontrol altında tutma imkanı verir. Ayrıca değişkenler arasındaki doğrusallığı azaltması ve bu sayede daha güvenilir sonuçlar vermesi panel veri analizinin avantajları arasında gösterilebilir (Baltagi, 2001; Hsiao 2003).

Çalışmada sahiplik yoğunlaşmasının temettü dağıtım kararlarına etkisini tespit etmek amacıyla oluşturulan modelde; literatürde yer alan çalışmalarla da uyumlu bir şekilde, temettü verimi değişkeni bağımlı değişken olarak kullanılmıştır. Sahiplik yoğunlaşması değişkeni bağımsız değişken, aktif karlılığı, kaldıraç oranı, PD/DD oranı ve yatırım harcamaları da kontrol değişkeni olarak kullanılmıştır. Faccio vd. (2001), Mancinelli ve Özkan (2006) ve Smit ve Eije (2009), yaptıkları çalışmada, bağımlı değişken olarak dağıtılan toplam nakit temettünün piyasa değerine oranını kullanmıştır. Mancinelli ve Özkan (2006) ve Smit ve Eije (2009), temettü dağıtım oranı hesaplanırken paydada yer alan karlılığın değişik muhasebe hileleri ile manipüle edilebildiğini belirterek, toplam nakit temettünün piyasa değerine oranının yapılacak çalışmalarda kullanılmasının faydalı olacağını belirtmiştir. Söz konusu oranın bir diğer avantajı da, zarar eden firmalarda temettü dağıtım oranının negatif bir değer alabilmesi veya karlılığı sıfıra yakın olan firmalarda temettü dağıtım oranının çok yüksek düzeylere çıkması nedeniyle gözlem değerlerinde oluşabilecek problemleri ortadan kaldırmasıdır (Schooley ve Barney, 1994; Gul, 1999; Bradford vd. 2013).

Konuyla ilgili yapılan çalışmalarda sermayenin $\% 5$ 'inden daha fazlasına sahip olanların toplam sermaye içerisindeki payının sahiplik yoğunlaşması değişkeni olarak sıklıkla kullanıldığı görülmektedir (örneğin Habibi vd. (2012). Bu çalışmada da söz konusu değişken bağımsız değişken olarak kullanılmıştır. Karlılığın dağıtılacak temettü tutarı üzerinde son derece önemli ve belirleyici bir değişken olduğundan hareketle, karlılığı temsilen ROA oranı kontrol değişkeni olarak kullanılmıştır (Harada ve Nguyen, 2006). Fama ve French (2002), diğer koşullar sabitken, daha karlı firmaların daha fazla temettü ödediklerini, fakat temettü dağıtım oranı ile kaldıraç ve yatııım fırsatları ilişkisinin negatif yönde olduğunu belirtmiştir (Fama ve French, 2002: 4). Temettü dağıtım kararlarını etkileyen önemli faktörlerden biri olan borçlanma düzeyi de kontrol değişkeni olarak kullanılmıştır (Gugler ve Yurtoglu, 2003; Harada ve Nguyen, 2006; Ramli, 2010). 
Yüksek borçlanma oranına sahip firmalarda, borçların anapara ve faiz ödemelerinin yaratacağı finansal yük ve borçların nakit akışlarında yaratacağı daralma nedeniyle daha az temettü dağıtılmasına neden olacağı beklenebilir. Farinha (2003), borç verenler tarafından belirlenen şartlar ve kısıtlamalar nedeniyle kaldıraç oranı ile temettü dağııım oranı arasında negatif bir ilişkinin beklendiğini belirtmiştir. Gharaibeh vd. (2013), Jensen (1986)'in borç kullanımının hissedarlar arasındaki temsil problemlerini azaltmak için temettü ödemelerini kullanma intiyacını azaltacağı yönündeki bulgularından hareketle, kaldıraç oranı ile temettü ödemeleri arasında negatif yönlü bir ilişkinin olacağını ifade etmiştir. Kontrol değişkenlerinden bir diğeri de yatıım harcamalarıdır (Bøhren vd., 2012). Firmaların gelecek dönemde yapacağı yatırım harcamalarının temettü ödemeleri üzerinde belirleyici bir rol oynaması nedeniyle, yatırım harcamaları da modele kontrol değişkeni olarak eklenmiştir. Gelecek dönemde daha fazla/az yatırım yapacak olan firmaların, ortaya çıkacak nakit ihtiyaçları nedeniyle daha fazla otofinansmana gidip daha az/fazla temettü dağıtması beklenebilir. Rozeff (1982), firmaların yatırım politikalarının temettü politikasını etkilediğini, diğer koşullar sabitken daha fazla yatırım yapacak olan firmaların daha az temettü ödeyeceklerini belirtmiştir. Kontrol değişkeni olarak kullanılan son değişken ise PD/ DD oranıdır (Chen vd., 2005; Harada ve Nguyen 2006; Mancinelli ve Özkan 2006). Fama ve French (2002), firmaların yatırım fırsatlarını temsilen PD/DD oranını kullanmıs ve gelecekte büyüme fırsatları olan firmaların daha az temettü ödeyeceklerini belirtmiştir. Thanatawee (2013), yüksek büyüme fırsatlarına sahip firmaların, gelecekteki yatırımları için muhtemelen daha fazla nakdi firmada bırakacakları için temettü ödemeleri ile gelecekteki büyüme fırsatları arasında negatif bir ilişkinin olacağını ifade etmiştir. Farinha (2003), Mancinelli ve Özkan (2006) ve Shubiri vd. (2012) de gelecekteki yatırım fırsatları ile temettü dağıtım oranı arasında negatif bir ilişkinin olacağını ileri sürmüşlerdir.

Temettü dağıtım kararlarının sahiplik yoğunlaşmasından nasıl etkilendiğini belirlemek amacıyla oluşturulan ekonometrik modellerde, $t$ dönemi sonunda, $t+1$ döneminde dağıtacağı temettü oranına karar vermeye çalışan firmaların, sahiplik yoğunlaşmasına ilaveten; $t$ dönemindeki karını, borçluluk düzeyini ve piyasa değeri$\mathrm{ni}$, ayrıca $\mathrm{t}+1$ döneminde yapacağı yatırım harcamalarını göz önünde bulunduracağı düşünülmüştür. Buna göre oluşturulan ekonometrik modeller aşağıda verilmiştir. Model 1, örneklemin tamamına panel Tobit yöntemiyle, Model 2 ise sadece kar dağııımı yapan firmalara sistem GMM yöntemiyle uygulanmıştır.

\section{Model 1 (TOBIT):}

$T V_{i, t}=\beta_{1} S Y_{i, t}+\beta_{2} R O A_{i, t-1}+\beta_{3} K A L D_{i, t-1}+\beta_{4} P D / D D_{i, t-1}+\beta_{5} Y A T_{i, t}+\varepsilon_{i, t}$

\section{Model 2 (GMM):}

$T V_{i, t}=\beta_{1} D S Y 1_{i, t}+\beta_{2} D S Y 2_{i, t}+\beta_{3} D S Y 3_{i, t}+\beta_{4} R O A_{i, t-1}+\beta_{5}$ $K A L D_{i, t-1}+\beta_{6} P D / D D_{i, t-1}+\beta_{7} Y A T_{i, t}+\varepsilon_{i, t}$

Model 1'de firmaların sahiplik yoğunlaşma düzeyleri arasındaki farklııklar gözetilmeksizin, sahiplik yoğunlaşması değişkeni tek bir bağımsız değişken olarak modele dahil edilmiştir. Model 2'de ise farklı olarak, sahiplik yoğunlaşması değişkenine kümeleme analizi yapılarak elde edilen, düşük, orta ve yüksek sahiplik yoğunlaşmasını temsil eden kukla değişkenler bağımsız değişken olarak kullanılmıştır. Modellerde kullanılan değişkenlerin tanımları Tablo 1'de yer almaktadır.

Tablo 1: Çalışmada Kullanılan Değişkenlerin Tanımları

\begin{tabular}{|l|l|}
\hline TV & $\begin{array}{l}\text { Temettü Verimi (t döneminde dağıtılan nakit } \\
\text { temettü/t-1 dönemindeki piyasa değeri) }\end{array}$ \\
\hline SY & $\begin{array}{l}\text { Sahiplik yoğunlaşması (\%5'ten fazla paya sahip tüm } \\
\text { ortakların toplam payı + Yöneticiler, aile üyeleri, fonlar } \\
\text { gibi stratejik diğer tüm ortaklıkların payları) }\end{array}$ \\
\hline DSY1 & $\begin{array}{l}\text { Kümeleme analizi sonucunda düşük sahiplik } \\
\text { yoğunlaşmasına sahip firmalar için oluşturulan kukla } \\
\text { değişken } \\
\text { (\%55>\%SY>\%7,65) }\end{array}$ \\
\hline DSY2 & $\begin{array}{l}\text { Kümeleme analizi sonucunda orta düzeyde sahiplik } \\
\text { yoğunlaşmasına sahip firmalar için oluşturulan kukla } \\
\text { değişken } \\
\text { (\%76>\%SY >\%55) }\end{array}$ \\
\hline DSY3 & $\begin{array}{l}\text { Kümeleme analizi sonucunda yüksek sahiplik } \\
\text { yoğunlaşmasına sahip firmalar için oluşturulan kukla } \\
\text { değişken } \\
\text { (\%99> \%SY >\%76 ) }\end{array}$ \\
\hline ROA & FVÖK/ Toplam Aktifler \\
\hline KALD & Toplam Borçlar / Toplam Aktifler \\
\hline PD/DD & Piyasa Değeri / Defter Değeri \\
\hline YAT & Sermaye harcamalarının doğal logaritması \\
\hline
\end{tabular}

Çalışmada muhtemel doğrusal olmayan ilişkileri tespit etmek amacıyla sahiplik yoğunlaşması değişkenine kümeleme analizi uygulanmış ve söz konusu değişken düşük, orta ve yüksek sahiplik yoğunlaşması olmak üzere üç gruba ayrılmıştır. Her bir gruba ait değerler Tablo 1'de verilmiştir. Diğer taraftan firmaların büyüme hızlarının temettü dağıtım kararlarında farklılıklara neden olabileceği düşüncesiyle, yine kümeleme analizi kullanılarak, firmalar aktif büyüme oranları ortalamalarına göre yüksek hızda büyüyen ve düşük hızda büyüyen firmalar olmak üzere iki gruba ayrılmıştır. Kümeleme analizi sonuçlarına göre yıllık ortalama $\% 7$ 'den daha fazla büyüyen firmalar yüksek hızda büyüyen, ortalama $\% 7$ 'den daha az büyüyen firmalar ise düşük hızda büyüyen firmalar şeklinde gruplandırılmıştır. Firmaların büyüme hızlarının temettü dağıtım kararları üzerindeki etkisini görmek amacıyla Model 2 düşük hızda büyüyen firmalar ve yüksek hızda büyü- 
yen firmalar için ayrı ayrı tahmin edilmiştir. Özellikle hızlı büyüyen ve yeterli tasarruf birikimi olmayan ülkelerde söz konusu ayrımın kar dağıtım kararları üzerinde; literatürle de uygun olarak, belirleyici olacağı düşünülmektedir.

Birinci modeli test etmede Tobit modellinin kullanılmasının nedeni, Temettü Verimi (TV) değişkeninin yapısından kaynaklanmaktadır. TV değişkeninin dağılımının verildiği Şekil 1'de de görüleceği üzere söz konusu değişken sol taraftan kısıtlanmıştır. TV değişkeninin sadece pozitif değerler alması ve bazı firmaların hiç temettü dağıtmaması, bazı firmaların ise bazı yıllar temettü dağıtması nedeniyle TV değişkeninin dağılımında sıfıra doğru sağ taraftan bir yığılma söz konusudur.

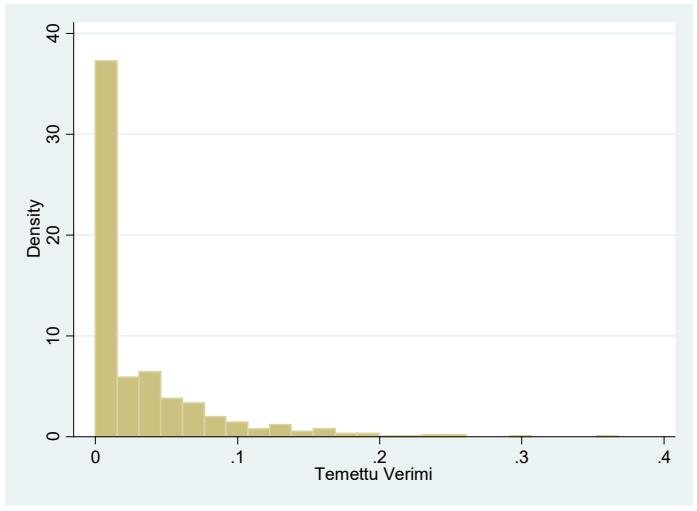

Şekil 1: Temettü Verimi Değişkeni Dağılımı

T döneminde dağıtılan nakit temettünün, $\mathrm{t}-1$ dönemindeki piyasa değerine bölünmesi ile hesaplanan TV değişkeninin hiçbir zaman negatif değerler alamayacağı açıktır. TV $\geq 0$ olması nedeniyle, çalışma kapsamında tercih edilen tahmin modeli kısıtlamalı bir regresyon modeli olan Tobit modelidir. Tobit modelleri kısıtlamalı, diğer bir ifade ile kısıtlanmış bağımlı değişkenlerin tahmininde tercih edilen bir modeldir. Veri setinin panel yapısında olmasına rağmen, Tobit modellerde, tahmin sırasında en yüksek olabilirlik yönteminin kullanılabilmesi nedeniyle, söz konusu modeli sadece rassal etkiler kısıtlamalı regresyon modeline uyarlamak mümkündür. Bu yüzden çalışma kapsamında rassal etkiler panel Tobit modeli kullanılmıştır.

Model 2'yi test etmede ise sistem GMM yaklaşımından faydalanılmıştır. Arellano ve Bover (1995) tarafından geliştirilen sistem GMM yaklaşımı fark denklemi ile düzey denklemlerinin birleştirilmesine dayanmaktadır. Bu yaklaşımda tahmincinin performansı, büyük ölçüde araç değişkenlerin geçerliliğine bağlıdır. Modeldeki varsayımlar aşııı belirleme testi gibi prosedürler kullanılarak test edilebilir. Bu doğrultuda gerçekleştirilen Hansen test sonuçları, model tahmin sonuçlarının yer aldığı tablolarda verilmiştir. Diğer taraftan dinamik panel veri modellerinde kullanılan diğer bir test de otokorelasyon (ardışık bağımlılık) testidir. Arellano ve Bond (1991)'un GM tahmincisinin tutarlılığının dayandığı en önemli varsayımlardan biri, birinci fark denkleminin hataları arasında ikinci dereceden korelasyon olmaması varsayımıdır. $\Delta u_{i t}$ ardışık bağımlı olmayan hataların birinci farkını gösterdiğinden $E \Delta u_{i t} \Delta u_{i t-1}{ }^{\prime}$ in sıfır olmasına gerek yokken GMM tahmincisinin tutarlılığı bir başka ifade ile otokorelasyonun varlığı tamamen $E$ $\Delta u_{i t} \Delta u_{i t-2}=0$ olmasına bağlıdır. Bu doğrultuda gerçekleştirilen test sonuçları, model tahmin sonuçlarının yer aldığı tabloda verilmiştir. Ayrıca GMM sonuçlarına ilave olarak, kukla değişkenlerin tahmin edilen katsayıları arasında anlamlı bir fark olup olmadığı da Wald testi kullanılarak test edilmiş ve sonuçlara ilave edilmiştir.

\section{4. ÇALIŞMADAN ELDE EDILEN BULGULAR}

Çalışmada öncelikle hem tüm örneklem için, hem de sadece kar dağıtan firmalardan oluşan örneklem için bağımlı, bağımsız ve kontrol değişkenlerinin ortalama değerleri incelenmiştir. Tablo 2 incelendiğinde, çalışma kapsamında yer alan tüm firmalardan oluşan örneklem için ortalama temettü veriminin \% 3, kar dağıtan firmalar için ise \%6 düzeyinde olduğu görülmektedir. Sahiplik yoğunlaşmasının ortalaması tüm örneklemde $\% 65,2$, kar dağıtımı yapan firmalar örnekleminde ise \% 66,7 düzeyindedir. İki örnekleme ait ortalama değerler karşılaştırıldığında, kar dağıtan firmaların daha karlı, daha az borçlu ve daha yüksek piyasa değerine sahip oldukları görülmektedir. Yatırım harcamalarının logaritması ve yatırım harcamalarının aktif toplamına oranları göz önünde bulundurulduğunda ise kar dağıtan ve dağıtmayan firmaların ortalamaları arasında önemli bir fark olmadığı görülmektedir.

Tablo 2: Değişkenlere Ait Ortalama Değerler

\begin{tabular}{|l|c|c|}
\hline & Tüm Örneklem & Kar Dağıtanlar \\
\hline TV & 0,03 & 0,061 \\
\hline SY & 65,2 & 66,7 \\
\hline ROA & 0,08 & 0,115 \\
\hline KALD & 0,224 & 0,165 \\
\hline PD/DD & 1,52 & 1,71 \\
\hline YAT & 9,07 & 9,81 \\
\hline YAT/Top. Aktif & 0,061 & 0,062 \\
\hline
\end{tabular}

Tablo 3'te kümeleme analizi sonucunda oluşturulan gruplar arasındaki varyans analizi sonuçlarına yer verilmiştir. Sahiplik yoğunlaşması değişkenleri için elde edilen analiz sonuçlarına göre, düşük, orta ve yüksek sahiplik yoğunlaşmasına sahip firmalar için sahiplik yoğunlaşmasının ortalama değerleri sırasıyla \%43,1, $\% 66,9$ ve $\% 83,7$ olarak gerçekleşmiştir. Ayrıca bu üç grup arasındaki farklar istatistiki olarak anlamlıdır. 
Tablo 3: ANOVA Test Sonuçları

\begin{tabular}{|l|c|c|c|c|c|c|}
\hline & $\begin{array}{c}\text { Düşük } \\
\text { Sahiplik Yoğ. } \\
\text { (1) }\end{array}$ & $\begin{array}{c}\text { Orta Sahiplik } \\
\text { Yoğunlaşması } \\
\text { (2) }\end{array}$ & $\begin{array}{c}\text { Yükssek } \\
\text { Sahiplik } \\
\text { Yoğunlaşması } \\
\mathbf{( 3 )}\end{array}$ & $\begin{array}{c}\mathbf{1 - 2} \\
\mathbf{p ~ D e g ̆ e r i ~}\end{array}$ & $\begin{array}{c}\mathbf{1 - 3} \\
\text { p Değeri }\end{array}$ & $\begin{array}{c}\mathbf{2 - 3} \\
\text { p Değeri }\end{array}$ \\
\hline $\begin{array}{l}\text { Sahiplik } \\
\text { Yoğunlaşması }\end{array}$ & 43,1 & 66,9 & 83,7 & $\mathbf{0 , 0 0 0}$ & $\mathbf{0 , 0 0 0}$ & $\mathbf{0 , 0 0 0}$ \\
\hline $\begin{array}{l}\text { Temettü Verimi } \\
\text { (Tüm Örneklem) }\end{array}$ & 0,05 & 0,072 & 0,052 & $\mathbf{0 , 0 4 2}$ & 0,976 & $\mathbf{0 , 0 2 6}$ \\
\hline $\begin{array}{l}\text { Temettü Verimi } \\
\text { (Yavaş Büy. } \\
\text { Firm.) }\end{array}$ & 0,066 & 0,077 & 0,068 & 0,693 & 0,985 & 0,721 \\
\hline $\begin{array}{l}\text { Temettü Verimi } \\
\text { (Hızlı Büy. Firm.) }\end{array}$ & 0,0384 & 0,07 & 0,0383 & $\mathbf{0 , 0 1 4}$ & 1,00 & $\mathbf{0 , 0 0 3}$ \\
\hline
\end{tabular}

Tüm örnekleme ait temettü verimi değişkeni için uygulanan varyans analizi sonuçları incelendiğinde, düşük, orta ve yüksek sahiplik yoğunlaşmasına sahip firmalarda temettü verimi ortalamasının sırasıyla $0,05,0,072$ ve 0,052 olduğu görülmektedir. Düşük ve yüksek sahiplik yoğunlaşmasına sahip firmaların temettü verimi ortalamaları $(0,05$ ve 0,052$)$ arasında istatistiksel olarak anlamlı bir fark yoktur. Fakat orta düzeyde sahiplik yoğunlaşmasına sahip firmaların temettü verimi ortalaması ile hem düşük hem de yüksek sahiplik yoğunlaşmasına sahip firmaların temettü verimi ortalaması arasında istatistiksel olarak anlamlı bir fark vardır. Orta düzeyde sahiplik yoğunlaşmasına sahip firmaların temettü verimi ortalaması, düşük ve yüksek düzeyde sahiplik yoğunlaşmasına sahip firmaların temettü verimi ortalamasından daha yüksektir. Yavaş büyüyen firmaların temettü verimi göz önünde bulundurulduğunda, düşük, orta ve yüksek sahiplik yoğunlaşmasına sahip firmaların ortalama temettü verimleri sırasıyla $0,066,0,077$ ve $0,068^{\prime}$ dir. Ancak varyans analizi sonuçlarına göre bu üç grubun temettü verimi ortalamaları arasında istatistiksel olarak anlamlı bir fark bulunmamaktadır. Hızlı büyüyen firmalarda, düşük ve yüksek sahiplik yoğunlaşmasına sahip firmaların temettü verimi ortalamalarının birbirine çok yakın değerler aldığı görülmektedir. Diğer taraftan orta düzeyde sahiplik yoğunlaşmasına sahip hızı büyüyen firmaların temettü veriminin, diğer iki grubun ortalama temettü veriminden daha yüksek olduğu görülmektedir. Hızlı büyüyen firmalar örnekleminde, tüm örneklem için yapılan varyans analizi sonuçları ile benzer sonuçlar elde edilmiştir. Yine düşük ve yüksek sahiplik yoğunlaşmasına sahip firmaların temettü verimi ortalamaları arasında istatistiksel olarak anlamlı bir fark yoktur. Orta düzeyde sahiplik yoğunlaşmasına sahip firmaların temettü verimi ile hem düşük hem de yüksek sahiplik yoğunlaşmasına sahip firmaların temettü verimi ortalamaları arasında istatistiksel olarak anlamlı bir fark vardır. Orta düzeyde sahiplik yoğunlaşmasına sahip firmaların temettü verimi ortalaması, düşük ve yüksek düzeyde sahiplik yoğunlaşmasına sahip firmaların temettü verimi ortalamasından daha yüksektir.

Tablo 3'te yer alan sonuçlar sahiplik yoğunlaşması arttıkça temettü veriminin belirli oranda arttığını ancak daha sonra azaldığını göstermektedir. Söz konusu doğrusal olmayan ilişki Şekil 2'de gösterilmiştir. Şekil 2'de de görüldüğü üzere orta düzeyde sahiplik yoğunlaşmasına sahip firmaların temettü verimi, düşük ve yüksek düzeyde sahiplik yoğunlaşmasına sahip firmaların temettü veriminden daha yüksektir. Ayrıca yavaş büyüyen firmalar ile karşılaştırıldığında, hızıı büyüyen firmalarda sahiplik yoğunlaşmasının düzeyine bağlı olarak temettü veriminde daha yüksek düzeyde bir değişim olduğu görülmektedir.

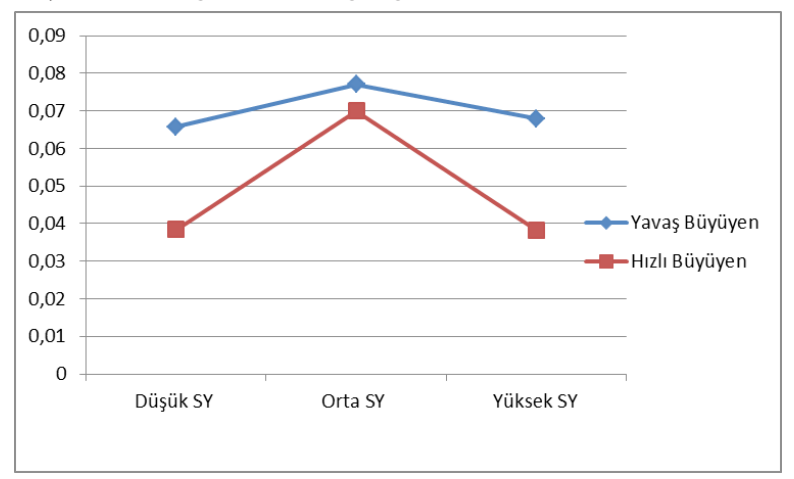

Şekil 2: Hızlı ve Yavaş Büyüyen Firmaların Temettü Verimi Grafiği

Tablo 4'te modelde yer alan değişkenler arasındaki korelasyon katsayıları yer almaktadır. Tablodan da görüleceği üzere sahiplik yoğunlaşmasının kar dağıtım kararlarına etkisini ölçmek amacıyla kurulan modellerde yer alan değişkenler arasında önemli sayılabilecek bir korelasyon bulunmamaktadır. 
Tablo 4: Korelasyon Matrisi

\begin{tabular}{|l|c|c|c|c|c|}
\hline & TV & SY & ROA & KALD. & PD/DD \\
\hline TV & 1 & & & & \\
\hline SY & 0,04 & 1 & & & \\
\hline ROA & 0,33 & 0,02 & 1 & & \\
\hline KALD & $-0,23$ & $-0,06$ & $-0,19$ & 1 & \\
\hline PD/DD & 0,019 & 0,07 & 0,04 & $-0,07$ & 1 \\
\hline YAT & $-0,007$ & $-0,033$ & 0,05 & 0,005 & $-0,005$ \\
\hline
\end{tabular}

Çalışma kapsamında yer alan firmaların tamamının yer aldığı tüm örneklem için uygulanan Model 1 'den elde edilen tahmin sonuçları Tablo 5 'te yer almaktadır. Rassal Etkili Panel Tobit yöntemi kullanılarak yapılan analiz sonuçlarına göre tahmin edilen Tobit modeli bir bütün olarak anlamlıdır. Tahmin sonuçlarına göre, kar dağıtım kararları ile sahiplik yoğunlaşması arasında doğrusal bir ilişki mevcuttur. Bir başka ifade ile sahiplik yoğunlaşması arttıkça kar dağıtım oranı da artmaktadır. Diğer taraftan karlılık, borçlanma düzeyi, piyasa değeri ve yatırım harcamaları da kar dağıtım kararlarını etkileyen diğer faktörlerdir. Aktif karlıığı, kar dağıtımı üzerinde en yüksek ve pozitif etkiye sahip değişken iken, diğer değişkenlerin kar dağıtım üzerindeki etkisi ters yönlüdür.

Tablo 5: Model 1 (Tobit Modeli) Tahmin Sonuçları

\begin{tabular}{|l|c|c|}
\hline & \multicolumn{2}{|c|}{ Bağımlı Değişken Temettü Verimi (TV) } \\
\hline SY & Katsayı Z İstatistiği \\
\hline ROA & 0,0007 & $2,32^{* * *}$ \\
\hline KALD & 0,2759 & $6,46^{* * *}$ \\
\hline PD/DD & $-0,1258$ & $-3,95^{* * *}$ \\
\hline YAT & $-0,0096$ & $-3,64^{* * *}$ \\
\hline SABiT & $-0,0095$ & $-3,41^{* * *}$ \\
\hline Gözlem Sayısı & $-0,1431$ & $-4,31^{* * *}$ \\
\hline Sol Sansürlü Gözlem Sayısı & & 441 \\
\hline Wald Ki Kare & \multicolumn{2}{|c|}{220} \\
\hline Log-Likelihood & $89,31^{* * *}$ \\
\hline
\end{tabular}

Not: Parantez içerisinde yer alan değerler tahmin edilen katsayıların olasılık değerlerini göstermektedir. ${ }^{* * *}, *^{* *} v{ }^{*}$ simgeleri katsayıların sırasıyla \%1, \%5 ve \%10 önem düzeyinde anlamlı olduğunu göstermektedir.

Çalışmada kar dağıtmaya karar veren firmalarda, sahiplik yoğunlaşmasının temettü dağıtım kararlarına etkisi de tespit edilmeye çalışılmıştır. Bu amaçla sadece temettü dağıtan firmalardan bir örneklem oluşturulmuş ve hem bu örneklemde yer alan tüm firmalar için hem de düşük hızda ve yüksek hızda büyüyen firmalar için sahiplik yoğunlaşmasının temettü dağıtım kararlarına etkisi Model 2 ile test edilmiştir. Elde edilen tahmin sonuçları Tablo 6'da sunulmuştur. Tablo 6'nın ilk sütununda tüm örneklem için Model 2'den elde edilen tahmin sonuçları yer almaktadır. Temettü dağıtan tüm firmalardan oluşan örneklemde, temettü verimi ile sahiplik yoğunlaşması değişkenleri ve karlılık oranı arasında istatistiksel olarak \% 1 önem düzeyinde anlamlı ve pozitif bir ilişkinin olduğu tespit edilmiştir.
Farklı sahiplik yoğunlaşması düzeyleri için oluşturulan kukla değişkenlerinin katsayıları arasındaki farklardan, sadece orta ve yüksek düzeyde sahiplik yoğunlaşması değişkenlerinin katsayıları arasındaki fark istatistiksel olarak anlamlı çıkmıştır. Bu sonuç orta düzeyde sahiplik yoğunlaşmasına sahip firmaların yüksek düzeyde sahiplik yoğunlaşmasında sahip firmalardan daha fazla temettü dağıttığını göstermektedir. Temettü verimi ile $\mathrm{PD} / \mathrm{DD}$ oranı ve yatırım harcamaları arasında ise istatistiksel olarak \% 1 önem düzeyinde anlamlı ve negatif bir ilişki vardır. Kaldıraç oranının katsayısı ise istatistiksel olarak anlamsız çıkmıştır. Buna göre, sahiplik yoğunlaşması ve karlılığın artması durumunda temettü verimi artarken, yatırım harcamaları ve PD/DD oranının artması durumunda temettü verimi düşmektedir. 
Tablo 6: Sistem GMM Tahmin Sonuçları (Kar Dağıtan Firmalar Örneklemi)

\begin{tabular}{|c|c|c|c|}
\hline & $\begin{array}{c}\text { MODEL 2 } \\
\text { (Tüm Örneklem) }\end{array}$ & $\begin{array}{c}\text { MODEL } 2 \\
\text { (Düşüük Hızda Büyüyen } \\
\text { Firmalar) }\end{array}$ & $\begin{array}{c}\text { MODEL } 2 \\
\text { (Yüksek Hızda Büyüyen } \\
\text { Firmalar) }\end{array}$ \\
\hline DSY1 & $\begin{array}{c}0,1877^{* * *} \\
(0,001)\end{array}$ & $\begin{array}{l}0,0072 \\
(0,931)\end{array}$ & $\begin{array}{c}0,1980^{* * *} \\
(0,003)\end{array}$ \\
\hline DSY2 & $\begin{array}{c}0,2118^{* * *} \\
(0,000)\end{array}$ & $\begin{array}{l}0,0395 \\
(0,590)\end{array}$ & $\begin{array}{c}0,2228^{* * *} \\
(0,001)\end{array}$ \\
\hline DSY3 & $\begin{array}{c}0,1521^{* * *} \\
(0,000)\end{array}$ & $\begin{array}{l}0,0300 \\
(0,678)\end{array}$ & $\begin{array}{c}0,1413^{* *} \\
(0,013)\end{array}$ \\
\hline ROA & $\begin{array}{c}0,3049^{* * *} \\
(0,000)\end{array}$ & $\begin{array}{c}0,364^{* * *} \\
(0,000)\end{array}$ & $\begin{array}{c}0,2260^{* * *} \\
(0,000)\end{array}$ \\
\hline KALD & $\begin{array}{l}0,0026 \\
(0,940)\end{array}$ & $\begin{array}{l}0,0909 \\
(0,292)\end{array}$ & $\begin{array}{r}-0,0314 \\
(0,385)\end{array}$ \\
\hline PD/DD & $\begin{array}{c}-0,0102^{* * *} \\
(0,000)\end{array}$ & $\begin{array}{c}-0,0087^{* * *} \\
(0,006)\end{array}$ & $\begin{array}{c}-0,0112^{*} \\
(0,062)\end{array}$ \\
\hline YAT & $\begin{array}{c}-0,0156^{* * *} \\
(0,000)\end{array}$ & $\begin{array}{r}-0,0007 \\
(0,920)\end{array}$ & $\begin{array}{c}-0,0144^{* * *} \\
(0,004)\end{array}$ \\
\hline Wald Ki-Kare & $\begin{array}{l}173,07 \\
(0,000)\end{array}$ & $\begin{array}{l}317,07 \\
(0,000)\end{array}$ & $\begin{array}{c}63,99 \\
(0,000)\end{array}$ \\
\hline Gözlem Sayısı & 308 & 125 & 183 \\
\hline Araç Değişken Sayısı & 55 & 55 & 55 \\
\hline $\operatorname{AR}(1)$ & $\begin{array}{c}-2,52 \\
(0,012)\end{array}$ & $\begin{array}{l}-1,91 \\
(0,056)\end{array}$ & $\begin{array}{c}-1,49 \\
(0,136)\end{array}$ \\
\hline $\operatorname{AR}(2)$ & $\begin{array}{c}0,15 \\
(0,880)\end{array}$ & $\begin{array}{c}-0,10 \\
(0,917)\end{array}$ & $\begin{array}{c}-0,11 \\
(0,913)\end{array}$ \\
\hline Hansen Aşırı Belirleme Testi & $\begin{array}{c}55,83 \\
(0,204)\end{array}$ & $\begin{array}{c}27,35 \\
(0,993)\end{array}$ & $\begin{array}{c}41,72 \\
(0,727)\end{array}$ \\
\hline $\mathrm{DSY} 1=\mathrm{DSY} 2$ & $\begin{array}{c}0,96 \\
(0,326)\end{array}$ & & $\begin{array}{c}1,31 \\
(0,2522)\end{array}$ \\
\hline $\mathrm{DSY} 1=\mathrm{DSY} 3$ & $\begin{array}{c}1,12 \\
(0,290)\end{array}$ & & $\begin{array}{c}3,73^{*} \\
(0,053)\end{array}$ \\
\hline $\mathrm{DSY} 2=\mathrm{DSY} 3$ & $\begin{array}{l}6,27^{* *} \\
(0,012)\end{array}$ & & $\begin{array}{l}9,39 * * * \\
(0,002)\end{array}$ \\
\hline
\end{tabular}

Not: Parantez içerisinde yer alan değerler tahmin edilen katsayıların olasılık değerlerini göstermektedir. ${ }^{* * *},{ }^{* *}$ ve ${ }^{*}$ simgeleri katsayıların sırasıyla \%1, \%5 ve \%10 önem düzeyinde anlamlı olduğunu göstermektedir.

Tablo 6'nın ikinci ve üçüncü sütununda düşük ve yüksek hızda büyüyen firmalar için oluşturulan modellerden elde edilen tahmin sonuçları yer almaktadır. Düşük hızda büyüyen firmalar için oluşturulan modelde, sadece karlılık oranı ve PD/DD oranı değişkenlerinin katsayıları istatistiksel olarak anlamlı çıkmıştır. Dolayısıyla düşük hızda büyüyen ve temettü dağıtan firmalarda sahiplik yoğunlaşmasının temettü verimini etkilemediği söylenebilir. Hızıı büyüyen firmalar için oluşturulan modelde ise kaldıraç oranı dışındaki tüm değişkenlerin katsayıları istatistiksel olarak anlamlı çıkmıştır. Kar dağıtımı yapan ve yüksek hızda büyüyen firmalarda, temettü verimi ile sahiplik yoğunlaşması ve karlılık arasında pozitif yönlü bir ilişki varken, PD/DD oranı ve yatırım harcamaları arasında negatif yönlü bir ilişki söz konusudur. Ayrıca farklı sahiplik yoğunlaşması için oluşturulan kukla değişkelerinin katsayıları arasındaki farklar göz önünde bulundurulduğunda, yüksek sahiplik yoğunlaşmasına sahip firma-
Iarın diğerlerine oranla daha az temettü dağıttıklarını söylemek mümkündür.

\section{SONUÇ}

Bu çalışmada 2004-2009 döneminde Borsa İstanbul'a kote 116 sanayi şirketinin verilerinden faydalanılarak, sahiplik yoğunlaşmasının temettü dağıtım kararlarına etkisi araştırılmıştır. Çalışmadan elde edilen bulgular bir bütün olarak değerlendirildiğinde, Easterbrook (1984) ve Jensen (1986)'in yaklaşımıyla uyumlu olarak, sahiplik yoğunlaşmasının temettü verimini pozitif yönde etkilediği sonucuna ulaşılmıştır. Ayrıca karlılık, borçlanma düzeyi, yatırım harcamaları ve piyasa değerinin firmaların temettü dağıtım kararları üzerinde önemli etkiye sahip olduğu tespit edilmiştir. Karlılık arttıkça firmalar daha fazla temettü dağıtırken, borçlanma düzeyi, yatırım harcamaları ve gelecekteki yatırım firsatlarını temsilen de kullanılan PD/ DD oranı arttıkça daha az temettü dağıtmaktadırlar. 
Sadece kar dağıtan firmalar göz önünde bulundurulduğunda, yoğunlaşma düzeyini temsil eden tüm kukla değişkenler ile karlılık, piyasa değeri ve yatırım değişkenlerinin firmaların kar dağıtım oranlarını belirlediği görülmektedir. Karın ne ölçüde dağıtılacağı kararında bu firmaların borçlanma düzeyleri ise etkili değildir. Bir başka ifade ile daha düşük borçlanma oranına sahip bu firmaların kararlarına borç ile ilgili yapacağı ödemeler etki etmemektedir. Diğer taraftan yoğunlaşma düzeyini temsil eden kukla değişkenlerin, tahmin edilen parametreleri arasında sadece orta ve yüksek düzeyde yoğunlaşma seviyesine sahip firmalar arasında anlamlı bir fark vardır. Orta düzeyde sahiplik yoğunlaşmasına sahip firmalar, yüksek düzeyde sahiplik yoğunlaşmasına sahip firmalardan daha yüksek oranlarda kar payı dağıtmaktadır. Kar dağıtan firmalardan oluşan örneklem, düşük ve yüksek hızda büyüyen firmalar olarak iki gruba ayrıldığında, düşük hızda büyüyen firmaların temettü dağıtım kararlarında sahiplik yoğunlaşmasının herhangi bir etkisinin olmadığı görülmüştür. Düşük hızda büyüyen firmaların temettü dağıtım kararlarında sadece karlılık ve piyasa değerinin etkili olduğu tespit edilmiştir. Hızıı büyüyen firmalarda ise temettü dağıtım kararlarının sahiplik yoğunlaşması, karlılık, piyasa değeri ve yatıım harcamaları tarafından belirlendiği ortaya konulmuştur. Ayrıca düşük, orta ve yüksek sahiplik yoğunlaşmasına sahip firmalar için oluşturulan kukla değişkelerin katsayıları arasındaki farklar göz önünde bulundurulduğunda, kar dağıtan firmalarda yüksek sahiplik yoğunlaşmasına sahip firmaların diğerlerine oranla daha az temettü dağıttıklarını söylemek mümkündür. 


\section{SON NOTLAR}

${ }^{1}$ Temsil maliyetleri, sahiplik ve yönetimin birbirinden ayrıldığı firmalarda, yöneticiler ile hissedarlar arasındaki çıkar çatışmasından kaynaklanan maliyetlerdir. Hakim hissedarlar ile küçük hissedarlar arasındaki veya hissedarlar ile borç verenler arasındaki çıkar çatışmaları da temsil problemlerine neden olmaktadır. Yöneticiler her zaman

hissedarların faydasını maksimize edecek kararlar almayabilir ve kendi faydalarını maksimize edecek bir davranış sergileyebilirler. Temsil maliyetleri, izleme maliyetleri, garanti sağlayıcı anlaşma maliyetleri ve önlenemeyen kayıplardan oluşmaktadır (Jensen ve Meckling, 1976).

\section{KAYNAKLAR}

Abdullah, N.M.H., Ahmad, Z. ve Roslan, S. (2012) "The Influence of Ownership Structure on the Firms Dividend Policy Based Lintner Model" International Review of Business Research Papers, 8(6): 71-88.

Ahmed, H. ve Javid, A.Y. (2009) "The Determinants of Dividend Policy in Pakistan" International Research Journal of Finance and Economics, 29: 110-125.

Al-Shubiri, F.N., Al Taleb, G. ve Al-Zoued, A.A. (2012) "The Relationship between Ownership Structure and Dividend Policy: An Empirical Investigation" Review of International Comparative Management, 13(4): 644-657.

Arellano, M. ve Bond, S. (1991) "Some Tests of Specification for Panel Data: Monte Carlo Evidence and an Application to Employment Equations" The Review of Economic Studies, 58(2): 277-297.

Arellano, M. ve Bover, O. (1995) "Another Look at the Instrumental Variable Estimation of Error-Components Models" Journal of Econometrics, 68(1): 29-51.

Baltagi, B.H. (2001) "Econometric Analysis of Panel Data” John Wiley and Sons Inc. UK, Chichester.

Berle, A.A. ve Means, G. C. (1932). "The Modern Corporation and Private Property" New York, Amerika Birleşik Devletleri: Macmillan.

Black, F. (1976) “The Dividend Puzzle" Journal of Portfolio Management, 2(2): 115-143.

Bøhren, Ø., Josefsen, M.G. ve Steen, P.E. (2012) "Stakeholder Conflicts and Dividend Policy" Journal of Banking and Finance, 36(10): 2852-2864.

Bradford, W., Chen, C. ve Zhu, S. (2013) "Cash Dividend Policy, Corporate Pyramids, and Ownership Structure: Evidence from China" International Review of Economics and Finance, 27: 445-464.

Chen, Z., Cheung, Y., Stouraitis, A. ve Wong, A.W. (2005) "Ownership Concentration, Firm Performance, and Dividend Policy in Hong Kong" Pacific-Basin Finance Journal, 13: 431-449.

Demsetz, H. (1983) "The Structure of Ownership and the Theory of the Firm" Journal of Law and Economics, 26(2): 375-390.
Demsetz, H. ve Lehn, K. (1985) “The Structure of Corporate Ownership: Causes and Consequences" Journal of Political Economy, 93(6): 1155-1177.

Easterbrook, F.H. (1984) "Two Agency Cost Explanations of Dividends" The American Economic Review, 74(4): 650-659.

Faccio, M., Lang, L.H. ve Young, L. (2001) "Dividend and Expropriation" The American Economic Review, 91(1): 54-78.

Fama, E.F. ve French, K.R. (2002) “Testing TradeOff and Pecking Order Predictions about Dividends and Debt" The Review of Financial Studies, 15(1): 1-33.

Farinha, J. (2003) "Dividend Policy, Corporate Governance and the Managerial Entrenchment Hypothesis: An Empirical Analysis" Journal of Business Finance \& Accounting, 30(9-10): 1173-1209.

Gharaibeh, M., Zurigat, Z. ve Al-Harahsheh, K. (2013) "The Effect of Ownership Structure on Dividends Policy in Jordanian Companies" Interdisciplinary Journal of Contemporary Research in Business, 4(9): 769-796.

Gugler, K. (2003) “Corporate Governance, Dividend Payout Policy, and the Interrelation between Dividends, R\&D, and Capital Investment." Journal of Banking \& Finance, 27(7): 1297-1321.

Gugler, K. ve Yurtoglu, B. (2003) "Corporate Governance and Dividend Pay-Out Policy in Germany" European Economic Review, 47(4): 731-758.

Gul, F.A. (1999) "Government Share Ownership, Investment Opportunity Set and Corporate Policy Choice in China” Pacific-Basin Finance Journal, 7(2): 157-172.

Gürsoy, G. and Aydoğan, K., (1999), "Equity Ownership Structure, Risk-Taking and Performance: An Empirical Investigation in Turkish Companies" International Global Finance Conference, 1998, Istanbul ve ERC/ METU International Conference in Economics, 1999, Ankara. http://www.bilkent.edu.tr/ aydogan/OwnershipStructure.pdf 
Habibi, S., Talebnia, G. ve Dost, M.F. (2012) "The Relationship between Ownership Concentration, Financial Performance and Profit Distribution Policy" Trends in Social Science, 5(1): 64-71.

Harada, K. ve Nguyen, P. (2006) "Ownership Concentration, Agency Conflicts, and Dividend Policy in Japan" (SSRN No: 953433). Retrieved 2014, July 17, from http://ssrn.com/abstract=953433

Holderness, C.G. (2003) "A Survey of Blockholders and Corporate Control" Economic Policy Review, 9(1): 51-64.

Hsiao, C. (2003) "Analysis of Panel Data" Cambridge, Birleşik Krallık: Cambridge University Press.

Jensen, M.C. (1986) Agency Cost of Free Cash Flow, Corporate Finance, and Takeovers" The American Economic Review, 76(2): 323-329.

Jensen, M.C. ve Meckling, W.H. (1976) "Theory of the Firm: Managerial Behavior, Agency Costs and Ownership Structure" Journal of Financial Economics, 3(4): 305-360.

Khan, T. (2006) "Company Dividends and Ownership Structure: Evidence from UK Panel Data" The Economic Journal, 116(510): 172-189.

La Porta, R., Lopez-De-Silanes, F., Shleifer, A. ve Vishny, R. (2000) "Agency Problem and Dividend Policies around the World" Journal of Finance, 55(1): 1-33.

Mancinelli, L. ve Özkan, A. (2006) "Ownership Structure and Dividend Policy: Evidence from Italian Firms" The European Journal of Finance, 12(3): 265-282.

Maury, C. B. ve Pajuste, A. (2002) "Controlling Shareholders, Agency Problems, and Dividend Policy in Finland" Stockholm School of Economics No. LTA 1/02. Retrieved 2014, October 10, from http://lta.hse. fi/2002/1/lta_2002_01_a1.pdf

Mehrani, S., Moradi, M. ve Eskandar, H. (2011) "Ownership Structure and Dividend Policy Evidence from Iran" African Journal of Business Management, 5(17): 7516-7525.

Miller, M. H. ve Modigliani, F. (1961). "Dividend Policy, Growth, and the Valuation of Shares" The Journal of Business, 34(4): 411-433.
Ramli, N.M. (2010) "Ownership Structure and Dividend Policy: Evidence from Malaysian Companies" International Review of Business Research Papers, 6(1): 170-180.

Rezaloie, A., Zariean, M. ve Bjarkenari, M.A. (2013) "Relationship between Ownership Structure and Dividend Policy in Iran" International Research Journal of Applied and Basic Sciences, 4(7): 1984-1990.

Rozeff, M.S. (1982) "Growth, Beta and Agency Costs as Determinants of Dividend Payout Ratios" Journal of Financial Research, 5(3): 249-259.

Schooley, D.K. ve Barney, L.D. (1994) "Using Dividend Policy and Managerial Ownership to Reduce Agency Costs" The Journal of Financial Research, 17(3): 363-373.

Sharif, S.J.S., Salehi, M. ve Bahadori, H. (2010) "Ownership Structure of Iranian Evidence and Payout Ratio. Asian Social Science, 6(7): 36-42.

Shleifer, A. ve Vishny, R.W. (1986) "Large Shareholders and Corporate Control" The Journal of Political Economy, 94(3): 461-488.

Shleifer, A. ve Vishny, R.W. (1997) "A Survey of Corporate Governanc" The Journal of Finance, 52(2): $737-$ 783.

Smit, M. ve Eije H.V. (November 30, 2009) "Ownership and Dividend Policy: New Evidence from Germany" Retrieved April 2, 2014, from http://www.fma. org/Hamburg/Papers/ OwnershipanddividendpolicynewevidencefromGermany.pdf

Thanatawee, Y. (2013) "Ownership Structure and Dividend Policy: Evidence from Thailand" International Journal of Economics and Finance, 5(1): 121-132.

Thomsen, S. (2005) "Conflicts of Interest Aligned Incentives? Blockholder Ownership, Dividends and Firm Value in the US and EU" European Business Organization Law Review, 6(2): 201-225.

Yıldız, B., Gökbulut, R.İ. ve Korkmaz, T. (2014) "Firmalarda Temettü Politikalarını Etkileyen Unsurlar: BIST Sanayi İşletmeleri Üzerine Bir Panel Veri Uygulaması" Ekonomik ve Sosyal Arasstırmalar Dergisi, 10(1): 259-292. 
